Веселина В. Ђуркин ${ }^{*}$

Универзитет у Новом Саду

https://doi.org/10.18485/ai_zsjoski.2018.1.11

Педагошки факултет у Сомбору

Катедра за језик и књижевност

\title{
ПРИМЈЕРИ УПОТРЕБЕ ДРУГИХ ФУНКЦИОНАЛНИХ СТИЛОВА У АНДРИЋЕВОМ ДЈЕЛУ
}

У раду се на корпусу романа и приповједака И. Андрића анализирају примјери употребе специјалних функционалних стилова - публицистичког, административног и научног, превасходно начини и разлози њихове употребе. Проведена анализа одабраних дјела показује да се у Андрићевом књижевном тексту елементи, мањи или већи сегменти датих стилова појављују у различитим синтаксичким формама, и то не само у функцији говорне карактеризације лика, постизања одређеног аргументативног, естетског, иронијског или комичног ефекта већ и ради остварења критичке дистанце наспрам говорних представника датих стилова који се, премда створени с циљем да се подупре и осигура процес комуникације, могу посувратити и тако дехуманизовати човјека, односе међу људима и постати моћно оруђе у рукама државе и владајуће идеологије, што се најбоље огледа у сучељавању језика датих стилова са разговорним стилом.

Кључне ријечи: Иво Андрић, књижевноумјетнички стил, специјални функционални стилови.

* veselina@pef.uns.ac.rs; veselinaso@gmail.com

* Рад је урађен у оквиру пројекта 178014 Динамика структура савременог српског језика, који финансира Министарство просвете, науке и технолошког развоја Републике Србије. 
Опште је познато да је књижевноумјетнички стил отворен ка свим другим функционалним стиловима. Све што је у функцији књижевног дјела у њему је допуштено. То је стил у којем је „individualna sloboda najveća. Zapravo bi bilo vrlo teško tu individualnu slobodu ograničiti. I zato se ne bi bilo teško složiti s onima koji smatraju da je ta individualna sloboda potpuna, neograničena, te da je u tome smislu književnoumjetnički stil stil sui generis" (Силић 2006: 100). Отуда не чуди чињеница да је још од најстаријих времена „'искакао' из функционалностилских класификационих критеријума" (Ковачевић 2016: 25). Као такав, овај стил може инкорпорисати елементе, сегменте, мање или веће структурне цјелине из свих других стилова, под условом да је то у служби примарно поетске/естетске функције, што га чини јединственим у систему функционалих стилова. Преузети елементи у новом окружењу попримају и нове карактеристике, губе своју примарну намјену и потчињавају се општој умјетничкој идеји, усложњавајући структуру и значење самог књижевноумјетничког текста, проширујући његов семантички и стилогени потенцијал.

Према критеријумима који су у поимању односа књижевног језика и језика књижевности важили до шездесетих година XX вијека ${ }^{1}$, Андрићев језик оцијењен је као језик који је „потпуно у границама књижевног 'канона', а Андрић као писац који, ријечи су Белићеве, „не тражи ефекта каквим насиљем над правилношћу књижевног језика”. Премда „свугде одише њоме”, тај језик није „укочен” већ има „потпуну гипкост”, која је у унутрашњем богатству језика - „богатству значења и комбинација у које речи могу улазити”. Та правилност је „нешто што се подразумева, као на пр.: ваздух или светлост или као што

1 О односу књижевног језика и језика књижевности в. Ковачевић 2016. 
човек мора бити пристојно обучен кад је у друштву. Иако је ту, она се нарочито не истиче и нарочито не осећа." (Белић 1937, Богаћење језика, 97-100).

Битно другачији поглед на однос књижевног језика и језика књижевности код Срба формиран је у другој половини XX вијека, а на њега је посебно утицала спознаја о поступку пререгистрације (деведесетих година), „као стилске 'интеграције' нелитерарних текстова у литерарне” (Ковачевић 2016: 24-25), на темељу којег се књижевноумјетнички стил диференцира од осталих функционалних стилова (и на макростилистичком плану), премда својеврсна мјешавина стилова „nije odlika samo književnosti. I drugi tekstovi često su multiregistarski diskursi, o čemu svjedoči i nova historiografija, i reklame ${ }^{2}$, i žurnalistički tekstovi, i eseji, i stripovi” (Катнић Бакаршић 2001: 283).

Такав поступак функционалног прилагођавања некњижених стилова (разговорног, административног, публицистичког и научног), њихових елемената, жанрова и подстилова умјетничкој идеји и естетској функцији књижевног дјела у научној литератури означен је термином пререгистрација. Пререгистрација представља заправо „белетризацију ('покњижевњење') некњижевних елемената или поступака, с тим да се под белетризацијом разумију процеси и разлози употребе некњижевноумјетничких стилова, жанрова или њихових елемената у књижевноумјетничке сврхе" (Ковачевић 2017: 28). ${ }^{3}$

2 И у језику рекламе као и у књижевноумјетничком стилу индивидуална слобода је највећа. У њему се сматра прихватљивим „sve ono što je namjerno, sve ono što pridonosi uočljivosti reklame i dovodi do prodaje reklamnog proizvoda. Može se odstupiti od svake (...) norme..." (Худечек, Михаљевић 2009: 186-187). У њој се преплићу различити језички дискурси (Столац, Властелић 2014: 39).

3 Према Ковачевићу (2017: 29), „Сва би се пререгистрација по својим посљедицама могла подвести под хибридизацију језика књижевности". Термин хибридни језик он темељи на Бахтиновом термину хибридна конструкција дајући му шире значење, а 
Премда је у књижевном тексту најчешће преосмишљавање, превођење разговорног стила и језика ${ }^{4}$ у књижевноумјетнички, у фокусу наше анализе биће примјери употребе специјалних функционалних стилова - публицистичког, административног и научног, превасходно начини и разлози њихове употребе, будући да нас ка томе води главнина одабраног корпуса, коју чине дјела (романи На Дрини ћуприја, Травничка хроника, Госпођица и приповијетке) за која можемо рећи да престављају и неку врсту умјетничког свједочанства о зачецима стварања појединих стилова.

Важна тематска компонента ових романа јесте додир Истока и Запада, сукоб старе и нове егзистенције, у којем су се „сталне и непроменљиве навике домаћег света

хибридна конструкција једна је од суштинских привилегија романескне прозе, недоступна драмским и чисто пјесничким жанровима, и представља „'исказ који по својим граматичким (синтаксичким) и композиционим обележјима припада једном говорнику, али у којем су стварно помешана два исказа, два говорна манира, два стила, два 'језика', два смисаона и два вредносна видокруга"' (Исто, 63). У своме раду о специфичним поступцима пререгистрације у роману „Кукавичја пилад” Лабуда Драгића, Ковачевић скреће пажњу на књижевна дјела чији језик, захваљујући специфичним поступцима пререгистрације, може бити окарактерисан као тотални хибридни језик, „с тешко ухватљивим границама учешћа других 'језика' или стилова” (нпр. језик књижевних дјела Радована Белог Марковића) или као „готово хибридни језик, у коме се ипак могу, мада тешко, диференцирати идиоматске и функционалностилске компоненте" (Ковачевић 2017: 27).

4 Б. Тошовић (2002: 382) препоручује разликовање термина усмени говор (разговорни језик) и разговорни стил. Усмени говор је сваки облик усменог изражавања и реализује се кроз говорне форме осталих функционалних стилова, док је разговорни стил начин изражавања који има незваничан, неприпремљен, спонтан карактер. (Усмени говор, тј. разговорни језик је и радио драма, и научна дискусија, и јавно предавање и иступи на суду, и разговор људи на улици, док је разговорни стил само ово посљедње). 
сударале са новинама које су туђинци и њихов поредак доносили”, при чему је оно старо и домаће „било редовито осуђено на попуштање и прилагођавање”, а ново у ствари и није било ново, већ „узбудљива илузија ширине и снаге".

Са новим, разноврсним дјелатностима и видовима друштвеног живота, ствара се и нов језик да би их изразио, засићен страним ријечима и изразима, који код домаћег свијета изазивају (као и свака друга новина) потиштеност, незадовољство, страх, отпор и мржњу, што потврђују сљедећи ексцерпирани примјери:

Na kapiji sede danju potišteni varoški muslimani, stariji ljudi, po desetak njih oko jednog, mlađeg, koji im čita novine, tumači strane izraze i neobična imena i objašnjava geografiju. (НДТ, 490); U Brankovića kuće ne sme da uđe nijedan komadić nove nošnje ili obuće ni nova alatka ili nova reč. Nijednom od sinova ne da ni u kakav posao koji je u vezi sa novom vlasti, unučad ne pušta u školu. (НДТ, 418); Prvi put se tada u kasabi čula reč „štrajk”. Mlade kalfe su se uozbiljile. Uveče, na kapiji, oni su vodili između sebe drugima nerazumljive razgovore i izmenjivali male brošure bez korica, sa naslovima „Šta je socijalizam?”, „Osam sati rada, osam sati odmora, osam naobrazbe”, „Ciljevi i putevi svjetskog proletarijata”. (НДТ, 478); Studenti donesu u isto vreme i nove reči i pošalice, nove pesme, nove igre sa zimušnjih balova, a naročito nove knjige i brošure, srpske, češke i nemačke. (НДЋ, 491); Hodža je mrzeo sve nove izraze, a naročito to „itakodalje”. Nije samo stoga što mu je paralo uši, nego što je jasno osećao da sama ta reč u govoru stranaca stoji umesto prećutane istine, kao i da sve ono što je ispred nje rečeno ne znači ništa. (НДТ, 484);

Укључивањем других функционалних стилова у књижевноумјетнички, Андрић, између осталог, не само да 
вјерније дочарава слику реалности - језичке реалности, чињенице да језик у пракси функционише као систем функционалних стилова, већ заправо износи умјетничку истину о тој чињеници, стављајући у први план проблем административизације и бирократизације датих стилова. Према ономе што у овим дјелима налазимо, све је, па и језик сам, у служби државе и одржања реда и поретка заснованог и утврђеног на темељима важеће идеологије ${ }^{5}$, а савршени службеници тог система, уједно и језички представници стилова савршено специјализованих у те сврхе, јесу прије свега правници, научници, просветни радници, новинари, дакле, сви они од којих је професија начинила, како писац каже, „створења нарочите врсте”, окренута против човјека и живота самог, који на свијет око себе гледају искључиво као на „подручје свога рада"; велики стручњаци и зналци, а у личном и породичном животу „велике шепртље”, „ништавила” и „крвопије”, неспособни да осјете самилост и макар и мало саучествују у туђој несрећи. О њиховој једнодимензионалности свједочи и начин на који их писац именује: чиновник-предавач, човек-судија, човек-правник и сл. За потврду реченом

5 У оквиру образложења у вези са „теоријски неочекиваном предности презента" у административном функционалном стилу са аспекта психолошких и идеолошких извора овакве праксе, Висковић закључује да је приказивање историјских друштвених односа као природних битан реквизит сваке идеологије, а употребом датог глаголског облика утврђује се „да су се неки друштвени односи уобичајено одвијали (код већине субјеката) још прије доношења правне норме управо онако како норма налаже, што значи да норма само потврђује оно што се већ као друштвена правилност збива”, као и то да „помоћу презента нормотворац подржава предоџбу о правној регулацији као спознаји 'нужних' и 'природних' токова друштвеног живота - прикривајући тако интересна и вољна обиљежја правних односа и правне регулације ради појачања њихове легитимности и мотивирајуће снаге" (Висковић 1989: 91). 
наводимо неколико примјера из анализираног корпуса, с напоменом да су курзивна истицања наша:

To je čovek-pravnik, i to onakav kakav je vladi i državnoj vlasti potreban, sa izuzetnom sposobnošću da u svakom sukobu između države, s jedne strane, i neke manje ustanove ili nekog pojedinca, s druge strane, ume brzo da nađe u nekom tekstu zakona ono mesto koje govori u korist države, i to jasno i ubedljivo. (ОПЛ, 142); To je Čovek-sudija koji na svet oko sebe gleda samo kao na područje svoga rada i poziva, i pri tome je uvek u miru sa samim sobom i svojom savešću. A, kao što je poznato, nema toga dobra, kao ni toga zla, koje ovakav ugledan pravnik mirne savesti nije sposoban da počini. (ОПЛ, 142); Bio je još vrlo mlad kad se u Stambolu pročuo kao vešt pravnik, odličan poznavalac zakonskih propisa, prekaljen činovnik i branilac državnih interesa. Od svoje profesije - tumačenja zakona i njihove primene na složene i nepredvidljive pojave života - izgradio je sebi visok životni poziv, a ta profesija načinila je od njega stvorenje naročite vrste. (ОПЛ, 141-142); Za njega su govorili da je „dubok pravnik” a on je i ostavljao utisak čoveka koji ume često da zaroni duboko u tu nauku, sve tamo negde do njenog dna, gde se kriju koreni ljudskih odnosa. Ono što bi sagledao dok se zadržavao u tim dubinama mora da je bilo strašno. Izgleda kao da mu se od toga lice zgrčilo u grimasu hladnog užasa, koju nije mogao docnije, kad se vratio na površinu, među ljude, nikad potpuno da razagna i zbriše. Ono što je tamo video i saznao, ubilo je u njemu veru u sve drugo osim u golo i tvrdo slovo zakona. Izgubio je svako razumevanje za čoveka i poslednji trag ljubavi ili sažaljenja prema ljudima, koje je u svojim shvatanjima i sudovima stavljao niže od svih živih bića. S vremenom, ljudi su za njega postali samo predmet za slobodnu igru i bezobzirnu primenu zakona; umeo je samo da im sudi, a sudio im je kao da su neživa priroda, pusti pesak ili mrtvi kamen. (ОПЛ, 141); Onaj ko bi posmatrao njega i njegov rad, mogao bi vek provesti razmišljajući o tom kakve 
veze ima ovaj činovnik-predavač sa pedagogijom, koja treba da podiže i stvara zdrave i srećne ljude i građane, kakve veze sa naukom ili umetnošću - i nikad ne bi našao odgovor na to pitanje. Ali, ukoliko je nastavni sistem tadašnjih austrijskih gimnazija u Bosni imao za cilj da u mladom čoveku i budućem građaninu uguši svaku klicu samostalnosti i ubije želju za ma čim originalnim, stvaralačkim, višim i lepšim, ovaj nastavnik je bio savršen službenik toga sistema. Bolje rečeno: on je nastojao svim silama da to bude. (Црвен цвет, 98); Sve su njihove naredbe takve, stroge, važne, i u osnovi besmislene, mislio je Alihodža i smeškao se u sebi kao dete koje prevari učitelja. (НДЋ, 552); Turski je zakon otprilike toliko godina, a postove mu ćaćine! — kao da je jutros pravljen za mene. (ПКС, 79); Činovnik nije bio isti i prisjednici su bili drugi, ali je zakon bio večito isti i sa njim i aga, miran, nenasrtljiv, siguran u svoje pravo. (ПКС, 79); I on je sa strahom mislio o mreži strašnih i svemoćnih zakona koja je isprepletena svuda i sputava sve i svakog; pobeći iz nje ne možeš, razmrsiti je ne umeš, jedino što možeš: da je u rakiji za trenutak zaboraviš. A nema uvek ni rakije. (ПКС, 79); To su ti zakoni i naredbe! Ti se smeješ, a oni te pogađaju pre ili posle, sigurno i neumoljivo. (ПКС, 79).

До које мјере може да се извитопери и поимање значаја и улоге науке, сазнајемо из приповијетке Црвен цвет. Као што не може бити да, рецимо, Василије Чокрљан ${ }^{6}$, професор латинског језика икада побјегне од

6 У РМС налазимо лексему чокрльа ж покр. чокот винове лозе (РЈA, РМС). Посебно је занимљива фигуративна употреба лексеме крља, чије једно ода значења има везе са лексемом чокрљьа, од које је и изведено презиме Чокрљан: крља 2. а. задебљали део чокота винове лозе, гиџа. крља фиг. а. онај који другога немилосрдно искоришћава и угњетава, крвопија. - Не жалите ни њих, ни јатаке њихове, нити изроде и крље нашег народа већ удрите (СЛ 1918, 1/3). б. досадна, несносна особа. Па иди од мене, крљо! (Крагујевац, Радој. Вл.). 
свог „ниског и тамног породичног порекла” брисањем „Издајничког звучног трага” у своме презимену и тако постане Васа Васиљевић, тако од једног чиновника, који је и саму „науку којој је 'служио” „гледао кроз текстове владиних расписа и наредаба, кроз разредну књигу и кроз свој нотес у ком је за њега био обухваћен цео свет, сређен по азбучном реду и оцењен оценама од један до пет", никада не може постати човјек који разумије племенитост и узвишеност научне мисли и свога позива:

Sve rimske i grčke klasike on je smatrao samo kao neku vrstu viših činovnika, profesora, viših jedino po rangu; svi su oni za njega u istoj državnoj službi u kojoj i on, i svi oni, zajedno sa njim i celim ostalim školskim sistemom, predstavljaju neku vrstu prepreke na putu koji đak treba da pretrči od detinjstva do činovničke karijere, tj. do hleba, položaja i društvenog ugleda. (Црвен цвет, 95); I na sve heroje antičkog sveta i na same bogove iz mitologije on je gledao kao na visoke dostojanstvenike „izvan ranga”, kao na neku vrstu više zvanične ustanove u državi kojoj služi i on. (Црвен цвет, 95); Po njemu su dečaci dolazili do zaključka da to što se zove latinski jezik i nije neki jezik koji su ma kada živi ljudi govorili, nego da je od svog postanka samo „nastavni predmet”, neka vrsta kazne i prokletstva, nešto kao rešetke koje dečaka odvajaju od svega onoga što ga privlači i čemu bi mogao da se raduje. (Црвен цвет, 94); Sve to treba da ubije u dečaku bujne životne nagone, da mu što više zakloni i život sam, da mu već na prvim koracima salomi volju i zagorča vek, pa da vidi - majčin sin! - šta je to karijera i kako se teško i skupo plaća, kako bi posle umeo da je ceni. (Црвен цвет, 95)

Ништа боље није приказан ни свијет научника, универзитетских професора. У роману Госпођица високообразована елита представљена је као слој људи ситна и слаба духа, користољубивих, неморалних себичњака и каријериста: 
Tim rečima je Jovanka završila razgovor sa profesorom, već rešena da njega uzme pod svoju zaštitu i „gura” protiv starih profesora koji su „kao mumije” zakrčili mlađim snagama pristup na Univerzitet... (Госпођица, 660)

У том су духу и оцјене новина (па и новинара) као моћног инструмента за манипулацију и обликовање људске свијести, који не служи само за прикупљање и преношење информација ${ }^{7}$, већ продире у све сфере друштва, окупира пажњу великог броја људи пружајући им сем информација, скандале, забаву, сензације:

Po običajima koji su tada vladali, kriminalna hronika zauzimala je mnogo mesta u dnevnoj štampi. Svi dnevni listovi iskorišćavali su ubistva, nesreće i krvave događaje da bi, raspaljujući maštu gomile, zagolicali njeno ljubopitstvo i, zadovoljavajući ga do u najsitnije pojedinosti, povećali prodaju lista. (Госпођица, 561); Sa takvim sećanjima i mislima sede starci na kapiji i slušaju slabo i rasejano šta pišu o svemu tome novine. Slušaju ćutke, iako im reči kojima se u novinama govori o carevima i državama izgledaju drske, lude i neumesne i ceo način pisanja kao nešto bezbožno, protivno večnim zakonima i logici života, nešto što „neće izdobriti” i sa čim se častan i razuman čovek ne može pomiriti. (НДЋ, 491); Novine nisu više nikad pomenule ime Rajke Radaković. Ni njen tadašnji život ni njena smrt nisu imali ničega što može da privuče pažnju i uzbudi maštu čitalačke gomile, ali njenu istinsku sudbinu pričaće vam stranice koje dolaze. (Госпођица, 561); Novine se čitaju pohlepno i mnogo ali površno i nadohvat: svak traži samo one koje na prvoj strani donose senzacionalne natpise, ispisane krupnim slovima. Sitno štampane i sabijene članke malo ko čita. Sve što se dešava, praćeno je šumom i bleskom krupnih reči. Mlađi svet ne smatra da je živeo toga dana, ako mu uveče, pre spavanja, ne zvone uši i ne blešte oči od

7 О производњи, контроли и власништву информација в. Зиновјев (2002: 250) 
onoga što je preko dana čuo i video. (НДЋ, 487); Pre nego što su pismeni ljudi mogli da se razaberu u protivrečnim novinskim vestima, rat između Turske i četiri balkanske države već je izbio i krenuo svojim drevnim putevima preko Balkana. (НДТ, 488); Ali ovoga puta nije novinama bilo suđeno da donesu duge reporterske izveštaje sa jezivim pojedinostima i fotografskim snimcima. (Госпођица, 561)

Међу новинама које су донијела окупаторска времена и нови људи јесу и неки од поменутих стилова. Једна од њих је, на примјер, како писац каже, велика и „код нас дотле непозната реклама", писмена и усмена ${ }^{8}$ :

„Okazion! Obaramo cijene! Okazion! Samo još danas!” „Likvidiramo sa gubitkom! Iskoristite današnji dan!” (Госпођица, 591)

Странац шпанског поријекла, по имену Рафо Конфорти, пословни партнер и десна рука Рајке Радаковић у „шапутавим”, лихварским пословима, своје прве кораке у трговинском послу подупире рекламом, као моћним оруђем за „инфицирање људи жудњом за посједовањем” и изванредним средством у стварању таквог идејно-психолошког стања „које утиче на њихово понашање усмјеравајући их у правцу каријеризма, преступништва, прилагођавања" (Зиновјев 2002: 230).

Рафина је реклама лишена естетске функције, банална. За њу се никако не би могло рећи да је умјетничка чињеница (какве су многе рекламе данас). Агре-

8 Напоменимо кратко да „Funkcionalna stilistika nije jednostavno odredila mjesto reklame u sistemu funkcionalnih stilova. U početku je bilo pokušaja da se reklama svrsta $u$ administrativni stil (po analogiji sa oglasima, ne uzimajući u obzir njihove različite jezične karakteristike i funkciju), zatim u publicistički, da bi se kasnije izdvojila u zaseban stil” (Катнић Бакаршић 2001: 186). 
сивна и претјерана - „Izlepio bi sve zidove i prozore svoga dućana crvenim i zelenim plakatima: 'Okazion! Obaramo cijene! Okazion! Samo još danas!' 'Likvidiramo sa gubitkom! Iskoristite današnji dan!" - примитивна и вулгарна, али зато врло дјелотворна jep „uvek poneko kupi nešto”.

У одабиру језичких средстава Рафо није креативан већ прагматичан. У његовој поруци доминира конативна функција, што се огледа у употреби 1. и 2. лица множине глагола (ликвидирамо, обарамо, радимо, искористите). Он је почетник, али врло вјешт, који недостатак аргумената, којим би потврдио квалитет робе, надомијешта експресивним исказима и експресивном лексиком, као и говором тијела, чиме појачава персуасивну вриједност поруке:

Pri govoru stalno polaže raširenu ruku nasred grudi i ponavlja: „Časti mi i imena! Časti mi i sreće!” (Госпођица, 591); Časti mi i sreće mi, likvidiramo sa gubitkom od $10 \%$ — viče Rafo govoreći uvek u množini. (Госпођица, 592); Vidiš ovo? Đubre neka je a ne roba, ako ne radimo sa gubitkom. (Госпођица, 592)

Рафо не даје опис производа, јер он продаје „свашта и ништа”. „Obično je zakupljivao 'partije' demodiranih ili izbledelih pomodnih artikala”. Он има лукаво осмишљену језичку стратегију како би изазвао акцију муштерија (подстакао на куповину) ${ }^{9}$, базирану на одличном познавању психологије великог броја људи, о којој свједочи и народна изрека да је „муфте и сирће слатко”. Зато Рафо тако вјешто скрива могућност сопствене користи од

9 Циљ сваке рекламе јесте створити позитиван контекст за производ и тиме стимулисати куповину. „'Reklama stavlja proizvod u najbolje moguće svjetlo i radi toga se koristi svim rasploživim i dopuštenim sredstvima"' (Столац, Властелић 2014: 20). У тој свјесној манипулацији ономе ко креира рекламне поруке на располагању су бројне језичке стратегије, посебно формуле увјеравања. "Jer korisnika/potrošača treba uvjeriti da mu taj i baš taj proizvod treba, ne neki drugi sličan na tržištu (a ima ih puno), nego baš taj” (Исто, 20). 
продаје, истичући у први план готово апсолутну добит купца. То постиже употребом реченичне конструкције Ликвидирамо са губитком, чије дејство, срачунато на похлепу и грамзивост, обезбјеђује понављањем и појачава исказима: Оказион! (згодна прилика да се ушићари) Само још данас! Искористите данашни дан!, то у писаној форми, а у говорној позивом на опкладу:

Ali da se kladimo! Pedeset kruna polažem, pedeset mojih sirotinjskih na tvojih pet gazdinskih i kladim se: da sa gubitkom radimo (Госпођица, 592).

Егзотизацију своје поруке остварује употребом ријечи страног поријекла (ликвидирамо, оказион, фактура), а њихово разумијевање препредено омогућује напоредном употребом свима разумљивих домаћих ријечи (радимо с губитком, обарамо иене).

У његовој реклами нема језичких поступака који би били резултат остварења лудичке функције (паронимских атракција, гласовног симболизма, каламбура, игре ријечима), чији је циљ да насмије и забави. Али има и забаве, и смијеха, и спектакла. Његова реклама је својеврстан перформанс, а Рафо се, посматран из перспективе савременог читаоца, чини као претеча данашњих „топ шопова”, који су окупирали телевизијски програм. За потврду реченом наводимо сљедећи одломак:

A najveću reklamu vrši Rafo sam koji se, onako pun, crven u licu i nasmejan, vrti kao čigra i stvara oko sebe vrtlog od smeha i razgovora. Pri govoru stalno polaže raširenu ruku nasred grudi i ponavlja: „Č́asti mi i imena! Časti mi i sreće!”

Sve što se desi u varoši, svaka reč koju neko kaže u prolazu, sve je to za njega povod za šalu, razgovor, viku i reklamu.

- Ne varaj narod, Rafo! - kaže neki šaljivdžija, u prolazu, Konfortiju koji upravo hvali neke stare kravate dvojici neodlučnih mušterija. 


\section{- ̌̌ta? Šta?}

Rafo ostavlja odmah onu dvojicu, istrčava na sredinu ulice, udarajući dlanom o dlan, ispreči se pred čoveka i ne da mu dalje. Njegove crne, španske oči zalivene su vlažnim sjajem, njegovo uzbuđenje jače od istinskog.

— Šta?! Ja varam narod? Ja! Časti mi i sreće mi, likvidiramo sa gubitkom od $10 \%$ - viče Rafo govoreći uvek u množini.

- Dobro, Rafo! Zna se! - kaže onaj i hoće da prođe, ali ga Rafo hvata za obe ruke.

- Šta se zna? Šta se zna? Uđi, uđi u radnju da ti pokažem fakturu. Faktura govori, gospodine! Ali da se kladimo! Pedeset kruna polažem, pedeset mojih sirotinjskih na tvojih pet gazdinskih i kladim se: da sa gubitkom radimo.

Rafo pritrčava širokoj tezgi, prihvata teatralnim pokretom kravatu, rasteže je i unosi čoveku u oči.

— Vidiš ovo? Đubre neka je a ne roba, ako ne radimo sa gubitkom. Uđi da vidiš fakturu, kad ti kažem, pa ako ispadne da lažem, sve ću ovo da razdijelim narodu banbadava.

Svet se zaustavlja, smeje, uživa u ovom prizoru koji se tako često ponavlja. A uvek ima poneko ko to prvi put sluša, i uvek poneko kupi nešto. (Госпођица, 591-592)

Реализујући рекламну поруку (на примитиван начин) не само у писаном виду (плакати црвени и зелени на којима су исписане рекламе) него и у разговорном језику, у синтаксичкој форми управног говора, у непосредном дијалогу продавца са муштеријама, писац разоткрива оно што реклама у својој суштини заправо јесте - превара. Помоћу добре рекламе људима се неријетко продаје оно што им не треба. ${ }^{10}$

10 О односу између истине и лажи у језику рекламе ауторке Д. Столац и А. Властелић (2014: 40) кажу сљедеће: „Zasigurno su u reklamnom tekstu neke od informacija neistine, neke su realn(ij) i podaci o proizvodu, ali većina bi ušla u kategoriju između smjelih laži i stvarnih podataka korisnih potrošaču. A ravnoteža se na vagi između istine i laži postiže upravo pažljivim izborom riječi”. 
Проведена анализа одабраних дјела показује да се у Андрићевом књижевном тексту елементи, мањи или већи сегменти датих стилова појављују у различитим синтаксичким формама, и то не само у функцији говорне карактеризације лика, постизања одређеног аргументативног, естетског, иронијског или комичног ефекта већ и ради остварења критичке дистанце наспрам говорних представника датих стилова.

Употријебљени у синтаксичкој форми управног говора, у оквиру дијалога, искази који по својим језичко-стилским одликама припадају неком од специјалних стилова супротстављени исказима разговорног стила најуспјешније илуструју до које мјере се дати стилови могу посувратити и удаљити не само од своје примарне улоге већ и од оног што се сматра „природним”, „нормалним”, „народним” језиком. А он је управо репрезентован разговорним функционалним стилом, који „нам при преласку на специјалне стилове помаже да разјаснимо и схватимо неке ствари", за који се каже да је антропоцентричан, конкретан, сликовит, метафоричан, да је варијанта стила која је најједноставнија и човјеку најближа (Катнић Бакаршић 2001: 94-105).

За потврду наводимо примјер дијалога у којем је научном сувопарном и објективном стилу, општим и апстрактним интерпретацијама, супротстављен живописан разговорни стил. У питању је разоговор између младог професора Херцеговца, етнографа, будућег доцента, којем је, као и многим младим људима, онемогућен приступ на Универзитет, а тиме осујећен и положај у друштву, и Јованке, пословне сараднице Рајке Радаковић (Госпођице), у којем она очекује потврду „сувих и вјерних” података о свом штићенику Ратку Ратковићу, због којег је доживјела велики сентиментални слом: 
- Postoji takav dinarski tip - završavao je profesor svoje izlaganje povodom Ratkovog slučaja - složen i do sada malo proučavan, u kome, nerazdvojno vezani, žive uporedo dva čoveka: jedan hrabar i čestit, a drugi strašljiv i moralno defektan.

- Hulja i kukavica - upala je suvo Jovanka kao da za nekoga prevodi ovu naučnu prozu na jasan ljudski govor.

- Ne, ne, molim vas, nemojte da me pogrešno razumete. Ima tu mnogo nijansa i rezervi bez kojih svaki zaključak ispada preteran i u osnovi netačan i nepravedan. Ta dva karaktera u jednom čoveku sudaraju se i mešaju u bezbrojnim ukrštanjima i prelivima, tako da mogu da prevare ne samo okolinu nego i dotičnog čoveka samog, pa da živi u potpunoj zabludi o sebi samom, o svojim karakternim osobinama i moralnoj vrednosti i pravom značenju svojih postupaka. Mladost je kritično doba za takvog čoveka. Tu se cela njegova ličnost savija ili lomi u jednom ili u drugom pravcu. I u tom vremenu postoji mogućnost da ceo njegov život krene putem predanog stvaranja kao i nepovratnim putem poroka i nerada.

- Vucibatina je to, ja vama kažem, profesore, čisto i bistro - odgovarala je Jovanka na sva učena i suptilna izlaganja mladog naučnika.

- U ovakvim vremenima - objašnjavao je profesor Jovanki - neposredno iza dugih i teških godina krvoprolića i stradanja, mladim ljudima izgleda njihova mladost ne kao ono što jeste: kratka pruga vremena u prirodnom razvoju jednog naraštaja, nego kao neki naročit božji dar, koji je samo jednom, izuzetno, pao s neba na zemlju, kao neka čudesna eksplozija snage i lepote. Sve što doživljuju i vide oko sebe izgleda im neočekivano, kao poklonjeno, spašeno ludim slučajem iz opšteg potopa da bi živelo nekim pobedničkim, prkosnim životom bez mere i granica.

- Vidim ja šta je. Ovo nije država nego ludnica. Sve sam kockar i badavadžija. Tim rečima je Jovanka završila razgovor 
sa profesorom, već rešena da njega uzme pod svoju zaštitu i "gura” protiv starih profesora koji su „kao mumije” zakrčili mlađim snagama pristup na Univerzitet, ali pre toga da izobliči Ratka Ratkovića, da naplati od njega što im duguje i, što je važnije, da ga „goni do božje kuće”. (Госпођица, 659-660)

Професор је „савршен тип незаинтересованог младића и честитог научника", скроман, повучен и предан науци. Да је ријеч о човјеку који има довољно знања и способности да да ваљану процјену и суд, у чију се позваност и компетенцију не може ни посумњати, свједочи и податак, саопштен у загради, да је нарочито подручје његових студија била „психологија човека динарског типа". Он говори са Јованком не знајући зашто га она испитује о његовом некадашњем школском другу, анализира објективно и без зле намјере. Али, сама чињеница да би Јованка могла бити та која крчи пут младим универзитетским снагама, податак да професор много воли да говори и да при том о свом школском другу говори као о случају, баца једно сасвим ново свјетло на све позитивне одлике младог професора и научника. Као представник висоокообразоване елите, професор говори књижевним језиком. На синтаксичком плану његово казивање одликује сложена и вишеструкосложена реченица ( $\mathrm{Ta}$ два карактера у једном човеку сударају се и мешају у безбројним укритаюима и преливима, тако да могу да преваре не само околину него и дотичног човека самог, па да живи у потпуној заблуди о себи самом, о својим карактерним особинама и моралној вредности и правом значену својих поступака), иначе својствена писаном језику (само је једна проста реченична структура: Младост је критично доба.), стога није случајно што писац у дидаскалији његово излагање назива научном прозом, коју супротставља „јасном људском говору”. То је својеврсна иронија, јер тиме алудира на прозу као „начин писменог 
изражавања у невезаном слогу, без метричких схема”, односно на „књижевни производ тако написан”. Управо тај „превод” професоровог излагања на обичан језик, на којем је све „јасно, чисто и бистро” ствара комичан и иронијски ефекат.

Сигурна у себе и своје процјене засноване на богатом животном искуству и базичним нагонима (ја вам кажем, професоре; Видим ја шта је; Ово није држава него луднииа; Хуљь и кукавица; Вуцибатина је то), као и сви људи који не сумњају у себе и критички не преиспитују своје ставове и поступке, Јованка наступа директно, отворено, без увијања, крајње лично, бахато, насупрот ученом, уопштеном, апстрактном и резервисаном излагању професора. Њен исказ је експресиван, емоционално набијен, што се огледа у употреби снижено маркиране лексике и елиптичних реченица (Хуль и кукавица; Вуцибатина је то; Све сам коцкар и бадавација), језгровит, без сувишних ријечи, јер Јованка је од акције, агресивна, одлучна да своје науме спроведе у дјело, на што указује употреба глагола: је већ решила, узме под заштиту, гура, изобличи, наплати, гони, прокрчи.

Мање или веће дијелове текстова других функционалних стилова писац инкорпорира у књижевни текст и као цитате ортографски маркиране знацима навода или знацима навода и курзивом:

a) Činovnik je čitao paragraf osmi:

„Ako kmet zanemari obrađivanje imanja i bez zakonitog povoda prestane da ga obrađuje, tako da vlasnik bude prikraćen u svom vlasničkom dohotku, ili ako na drugi način nanese štetu zakonitom vlasniku, ili ako bez važnog povoda odbije da preda vlasniku deo koji ovome pripada, ili, ukratko, ako radi protivno odredbama između njih sklopljenog ugovora, pa vlasnik podnese vlasti tužbu - tada će vlast, pošto ispita stvar i punovaljanim dokazima se uveri o opravdanosti podnesene tužbe, a ako nema izgleda da bi se 
kmet mogao popraviti, istoga udaljiti sa dotičnog kmetovskog selišta." (ПКС, 79)

6) Zažmurivši na desno oko, Alihodža je sricao tekst na turskom, i to samo one rečenice koje su štampane debljim slovima:

\section{„STANOVNICI BOSNE I HERCEGOVINE!”}

„Vojska Cara Austrijskog i Kralja Ugarskog prešla je granicu vaše zemlje. Ona ne dolazi kao neprijatelj da otme zemlju silom. Ona dolazi kao prijatelj da učini kraj neredima koji već godinama uznemiruju ne samo Bosnu i Hercegovinu nego i pogranične pokrajine Austro-Ugarske.

„Car i Kralj nije mogao više gledati kako nasilje i nemir vladaju u blizini njegovih pokrajina, kako bijeda i nevolja kucaju na granice njegovih zemalja. On je skrenuo pogled evropskih država na vaš položaj i u vijeću naroda jednoglasno je zaključeno da vam Austro-Ugarska vrati mir i blagostanje koje ste odavno izgubili.

„Njegovo Veličanstvo Sultan, kome vaše dobro leži na srcu, osjetio se ponukanim da vas povjeri zaštiti svoga moćnog prijatelja Cara i Kralja.

„Car i Kralj naređuje da svi sinovi ove zemlje uživaju ista prava po zakonu, da su im svima život, vjera i imetak zaštićeni.

„Stanovnici Bosne i Hercegovine! Stupajte sa povjerenjem pod zaštitu slavnih zastava Austro-Ugarske. Dočekujte naše vojnike kao prijatelje, pokoravajte se vlastima, vratite se na svoje poslove, plodovi vašeg truda biće zaštićeni." (НДТ, 405-406) 
в) Ovoga puta proglas nije bio i na turskom jeziku i hodža nije umeo da ga čita. Jedno momče čitalo je naglas, potpuno mehanički, kao u školi:

\section{PROGLAS}

na narod Bosne i Hercegovine

„Mi Franjo Josip I, Car Austrijski, Kralj češki itd. i Apo-apostolski Kralj Ugarski, stanovnicima Bosne i Hercegovine:

„Kad je ono prije jednog po-pokoljenja Naša vojska prekoračila granice Vašijeh zemalja..."

Alihodža oseti kako ga zabride desno uho ispod bele ahmedije, i kao da je juče bilo, iziđe mu pred oči svađa sa Karamanlijom, ono nasilje koje je tada nad njim izvršeno, pa crven krst kako pliva u suzama, dok njega švapski vojnik pažljivo otkiva, pa beo plakat sa ondašnjim proglasom na narod.

Momče je čitalo dalje:

„... dano Vam je uv-uv-jerenje da nijesu došli kao dušmani, nego kao Vaši prijatelji s čvrstom voljom da uklone sva zla koja su Vašu dodom-domovinu godinama teško pritiskala.

„Ova riječ, dana Vam u onom oz-ozbiljnom tre-nutnut-ku..."

Svi zagrajaše na neveštog čitača koji se, zbunjen i pocrveneo, izgubi među svetom, a na njegovo mesto dođe neki nepoznat čovek u kožnom kaputu, kao da je čekao na to, i stade da čita brzo i tečno, kao molitvu koju zna odavno napamet:

„Ova riječ, dana Vam u onom ozbiljnom trenutku, pošteno je odista održana. Naša vlada se uvijek ozbiljno trudila da, u miru i zakonitosti marljivo radeći, Vašu domovinu privede srećnijoj budućnosti.

„I Mi, na Našu veliku radost, smijemo slobodno reći: 
sjeme što je bačeno u brazde podrivanog tla, bogatom je nikli istjerano. I Vi isti morate to kao blagodat osjećati: da su namjesto sile i zuluma stupili red i sigurnost, da se rad i život nalaze u stalnom razvitku, da se oplemenjujući uticaj umnožene obrazovanosti pokazao i da se pod zaštitom uređene uprave može svak plodovima svoga rada veseliti.

„Sviju nas je ozbiljna dužnost da ovijem putem neumorno naprijed koračamo.

„Imajući tu metu pred očima držimo da je došlo vrijeme da stanovnicima obiju zemalja ukažemo nov dokaz naše vjere u njihovu političku zrelost. Da bi Bosnu i Hercegovinu podigli na viši stepen političkog života, odlučili smo Se podijeliti objema zemljama konstitucionalne ustanove - koje će odgovarati njihovijem prilikama i zajedničkijem interesima - i stvoriti na taj način zakonsku podlogu za predstavništvo njihovih želja i koristi.

„Neka se sluša i Vaša riječ, kad se unaprijed uzodlučuje o stvarima Vaše domovine, koja će kao i dosada imati svoju zasebnu upravu.

„No prvi je neophodni uslov za uvađanje ove zemaljske ustavnosti: opredjeljenje jasna i nesumnjiva pravnog položaja obiju zemalja. S toga razloga, a i držeći na pameti one veze koje su u starijim vremenima postojale između Našijeh dičnijeh Predaka na ugarskom prestolu i ovijeh zemalja, protežemo Mi prava Naše suverenosti na Bosnu i Hercegovinu i hoćemo da se i na ove zemlje primjenjuje red nasljedstva, koji vrijedi za Našu kuću.

„Tako će stanovnici obiju zemalja postati učesnici u svijem onijem dobročinstvima, što ih može pružiti trajno učvršćenje njihove dosadanje veze. Novi će poredak biti jamstvo da će kultura i blagostanje u Vašoj domovini naći sigurno ognjište.

„Bosanci i Hercegovci!

„Među mnogijem brigama, koje Naš presto okružuju neće unaprijed biti posljednja ona za Vaše materijalno i 
duhovno dobro. Viša misao jednakoga prava sviju pred zakonom: sudjelovanje pri donošenju zakona i u upravi zemlje; jednaka zaštita sviju vjeroispovijesti, jezika i nacionalne svojstvenosti - sva ova visoka dobra uživaćete u punoj mjeri.

„Sloboda pojedinca i dobro cjeline biće zvijezda vodilja Naše vlade za obadvije zemlje.

„Vi ćete se zato podsigurno pokazati dostojni povjerenja, koje se u Vas polaže, da će plemeniti sklad između vladara i naroda, taj najdragocjeniji zalog svega državnog napredka, Naš zajednički rad uvijek pratiti.

„Dano u Našem kraljevskom glavnom i prestonom gradu Budim-Pešti.

Franjo Josip, s. r."

Tako je završio čitanje čovek u kožnom kaputu i odjednom se neočekivano i jako prodrao:

— Živilo Njegovo Veličanstvo naš Car!

- Živiooo! — viknu onaj dugački Ferhat što pali opštinske fenjere, kao poručen. (НДЋ, 480-482)

Осим на морфосинтаксичком (употреба глаголских облика - превага презента над осталим глаголским облицима; недвосмислено исказивање односа субординације појачаном употребом императива: cmynajme, дочекујте, покоравајте се, вратите се; синонимија лица - употреба тзв. краљевског ми: Ми Фрағьо Jосип I; сложена и вишеструкосложена реченична структура, учестала употреба везника ако у тексту законодавно-правног подстила; архаизација исказа употребом наставака старих тврдих основа са елементом јат у зависним падежним облицима придјевско-замјеничке промјене: заједничкијем, овијем, юиховијем, многијем, нашијех, дичнијем; ред ријечи: свију нас је озбилнна дужност, протежемо Ми права Наше суверености, ... и да се ... може свак плодо- 
Примјери употребе других функционалних стилова... 215

вима свога рада веселити, богатом је никли истјерана) и лексичком плану (општеупотребна неекспресивна лексика и лексика специфична за текстове административног карактера и закондавно-правног подстила), цитирани дијелови текстова, ово посебно у случају наведених прогласа, разликују се и на ортографском (употреба великог слова при писању личних и присвојних замјеница: $M u$, Bac, Baм, Ce, Наша, Ваше, Његово; при писању назива владарских титула и присвојних придјева: Цар, Крал, Султан, Аустријски, Угарског) и на фонетском плану (ијекавска замјена гласа јат у прогласима: увјерене, повјеренем, покољеньа, вјера, нијесу, ријеч, вијећу).

Када се говори о језичко-стилским одликама прогласа народу, немогуће је заобићи питање кварења и страдања српског језика за вријеме аустријске владавине. За тај језик Кочић ће рећи да је једна „одурна”, „тешка и усиљена” наказа, „много пута потпуно неразумљива, без гипкости, еластичности и звучности, тих битних особина нашег крепког језика. То је језик као наш, а није наш. Наше су ријечи, али језик није наш" (Ковачевић 2015: 231-232 према Кочић Кочић 1961: 311-322). А размјере рогобатности и наказности таквога језика најбоље се дају сагледати у окружењу књижевноумјетничког текста какав је Андрићев.

Занимљиво је што цитирани текст или дио текста готово увијек неко чита, изговарајући или не изговарајући прочитано - сричући, течно или механички. Ауторске опаске о начину читања и о самоме читачу први су путокази за тумачење уврштеног текста и први сигнали који упућују на размјере тешкоћа које обичан човјек има у разумијевању њихове садржине:

Чиновник је читао параграф осми; Зажмуривши на десно око, Алихоџа је срицао текст на турском, и то само оне реченице које су штампане дебљим словима; Једно момче читало је наглас, потпуно механички, као у 
школи; Сви заграјаше на невештог читача који се, збуњен и поцрвенео, изгуби међу светом, а на његово место дође неки непознат човек у кожном капуту, као да је чекао на то, и стаде да чита брзо и течно, као молитву коју зна одавно напамет. [Истицање подвлачењем наше]

Сам начин читања цитираног текста представља први ниво његове интерпретације. Није случајно што „невјешто момче” које чита проглас управо замуцкује при изговарању оних ријечи које изазивају подозривост код домаћег свијета: Апо-апостолски Краль Угарски; дано Вам је ув-ув-јерене, да уклоне сва зла која су Вашу додом-домовину годинама тешко притискала; Ова ријеч, дана Вам у оном оз-озбибном тре-нут-нут-ку, нити је случајно да га „човјек у кожном капуту” чита брзо и течно као молитву и завршава узвикујући „Живило Његово Величанство наш Цар!” У том смислу ваља сагледати и дијелове ауторског говора уметнуте у цитирани текст, у којима се тај текст смијешта у шири контекст, неопходан за разумијевање његове суштине односно скривених намјера адресата (да покори и отме), што писац остварује или описом психосоматске реакције јунака на дати текст или саопштењем његовог унутарњег монолога у којем он анализира дијелове тога текста и преводи их на јасан и разумљив језик:

Alihodža oseti kako ga zabride desno uho ispod bele ahmedije, i kao da je juče bilo, iziđe mu pred oči svađa sa Karamanlijom, ono nasilje koje je tada nad njim izvršeno, pa crven krst kako pliva u suzama, dok njega švapski vojnik pažljivo otkiva, pa beo plakat sa ondašnjim proglasom na narod.

Malo otvorenih usta i nagnute glave, Alihodža je slušao te u većini neobične ili nepoznate reči, a i one koje mu same po sebi nisu strane dolaze mu u ovom sklopu nekako čudne i nerazumljive: „Sjeme... bačeno u brazde podrivanog tla”, „neophodni uslov za uvađanje ove zemaljske ustavnosti: 
opredjeljenje jasna i nesumnjiva pravnog položaja...”, „Zvijezda vodilja Naše vlade ..." Da, to su opet te „carske riječi!” A kod svake pojedine od njih pred unutarnjim pogledom hodžinim čas se otvori neki dalek, neobičan i opasan vidik, čas se spusti neka zavesa, crna i olovna, pred samim zenicama. Tako naizmence; ili ne vidi ništa ili vidi nešto što ne razume i što ne sluti na dobro. - U ovom životu ništa nije isključeno i svako je čudo mogućno. Evo gde čovek može pažljivo da sluša, a da ništa ponaosob ne razabire, i da sve zajedno potpuno shvati i pravilno razume! To seme, ta zvezda, te brige prestola, sve bi to moglo biti i na stranom nekom jeziku, a hodža bi ipak, čini mu se, razumeo šta se njima hoće da kaže i želi da postigne. Ovo se carevi, evo već trideset godina dovikuju preko zemalja i gradova i preko glava svojih naroda. A teška je svaka reč u svakom proglasu svakog cara. Zemlje se kidaju, glave lete od njih. Tako se to kaže „seme ... zvezda... brige prestola” da se ne bi moralo nazvati pravim imenom i kazati što jeste: da i zemlje i pokrajine, a sa njima i živi ljudi i njihova naselja, idu od ruke do ruke kao sitna para, da pravoveran i dobronameran čovek ne nalazi na zemlji mira, ni onoliko koliko mu za njegov kratki vek treba, da se njegovo stanje i imanje menja nezavisno od njega i protivno njegovim željama i najboljim namerama. (НДТ, 481-482).

Понекад се ортографски маркирани знацима навода у ауторском говору појављују само, на примјер, новински наслови или по једна реченица из неког текста административног каркатера (наредбе, циркуларног писма и сл.):

I ovu vest o smrti usamljene starice novine su objavile na vidnom mestu, sa golicavim podnaslovima: „Da li se radi o zločinu?”, „Istraga u toku. Naš reporter na licu mesta”. (Госпођица, 561); „Srpska vojna sila ne postoji više”, pisalo je krupnim slovima na čelu lista. (Госпођица, 617); Treba svakako otvoriti istragu, ali rezultat istrage je unapred sigu- 
ran: „U nastupu umne poremećenosti... itd.” (ОПЛ, 140); U drugom se propisivalo kako treba da se proslavi Napoleonov rođendan, 15. avgusta. „Troškove za orkestar i dekoracije bala koji tom prilikom priredi ima da snosi generalni konzul sam." Čitajući tu naredbu, Davil se gorko osmehnuo. (TX, 34)

Елементе специјалних стилова, обично публицистичког или административног, исказани ријечју или синтагмом, писац уклапа у књижевноумјетнички текст и као фрагментарне цитате у оквиру ауторског говора:

Socijaldemokratski list Sloboda napao je otvoreno Gospođicu, koja je odbila da da prilog za bolesnu radničku decu, i nazvao je „Šajlokom u suknji”. (Госпођица, 597-598); Kad se osetilo kolebanje u poslovanju banaka, ona je bila među prvima koji su povukli svoje uloge i sprečili da se „zamrznu”. (Госпођица, 675); U samoj zaradi Štaba, Kostaćeva sudbina vec je postala 2 predmet", koji je imao svoj broj i svoju oznaku „poverljivo". (ОПЛ, 139); Na drumu koji vodi u Lukavicu i koji je već izvan "područja grada Sarajeva” sastavila se odjednom velika povorka; nad njom su se vile crvene zastave, a svaki radnik bio je zakićen karanfilom od crvene hartije. (Црвен цвет, 100); Da bi suzbio takve vesti i opravdao se, počeo je da preduzima „protivmere”. (ОПЛ, 181); Najposle, neizbežno je bilo da i murtad-tabor oseti posledice seraskerovih „protivmera”. (ОПЛ, 181).

Осим у виду синтаксичко-стилистичких категорија управног говора, писац дијелове других функционалних стилова у књижевноумјетнички текст уводи и у синтаксичкој форми неуправног говора ${ }^{11}$ :

11 О синтаксичко-стилистичким варијантама као подмоделима управног и неуправног говора у српском књижевном језику в. Ковачевић (2013: 67-99). 
Jednog od poslednjih dana februara meseca 1935. godine sve su beogradske novine donele vest da je u Stiškoj ulici, $\mathrm{u}$ kući broj 16a, nađena mrtva sopstvenica te kuće (Госпођица, 561); Komisija, koja je odmah izišla u Stišku ulicu, utvrdila je brzo i nesumnjivo da nije u pitanju zločin, nego da je stara devojka umrla prirodnom smrću, od srčane kapi, a da je sve u kući neoštećeno i na svom mestu, bez traga provale i ma kakvog nasilja i krađe. (Госпођица, 561); Zbog toga su je napadale i sarajevske novine, sa jasnim aluzijama na njen način poslovanja. Srpska riječ je donela jednu belešku o tome kako neki potomci onih koji su osnovali i podržavali srpske ustanove u Sarajevu zanemaruju tu lepu tradiciju i, ogrezli u duhu materijalizma i ružne sebičnosti, zaboravljaju svoju dužnost prema narodu i narodnim društvima. (Госпођица, 597); Veso pokaza samo rukom na večernje novine pred sobom. U njima se krupnim slovima javljalo da je srpska vojska uništena i da se, napadnuta sa severa i jugoistoka od Nemaca, Austrijanaca i Bugara, povlači u neprohodne planine, ostavljajući za sobom sav materijal, ranjenike i bolesne. (Госпођица, 617); Umesto toga stizale su nerazumljive i rogobatne naredbe Direkcije računovodstva, cirkularna pisma bez ikakvog smisla, koja su Davilu, ovako usamljenom i napuštenom, izgledala kao prava ironija. $U$ jednom se na primer strogo nalagalo da se konzul ograniči na druženje sa stranim konzulima a da prijeme stranih ambasadora i poslanika može da posećuje samo ukoliko bi ga njegov ambasador ili poslanik pozvao da to učini. (TX, 34); Tako je jednog letnjeg dana, posle toliko vremena, iskrsnuo opet na kapiji beo, služben oglas. Bio je kratak, ovog puta opervažen jakom crnom prugom, i javljao je da je Njeno Veličanstvo carica Jelisaveta poginula u Ženevi, kao žrtva odvratnog atentata, od ruke italijanskog anarhiste Lukenija. Oglas je dalje sadržavao gnušanje i duboku žalost svih naroda velike Austro-Ugarske Monarhije i pozivao ih da se u podaničkoj vernosti još čvršće okupe oko prestola i da tako budu najbolja uteha vladaocu 
koga je sudbina tako teško pogodila. Plakat je bio prilepljen ispod bele ploče sa natpisom, kao nekad proglas generala Filipovića o okupaciji zemlje, i svet ga je čitao s uzbuđenjem, jer je bila reč o carici, ženi, ali bez pravog razumevanja i dubljeg učešća. (НДЋ, 467)

Да сведемо. У раду смо на корпусу романа и приповједака И. Андрића анализирали примјере употребе специјалних функционалних стилова - публицистичког, административног и научног, превасходно начине и разлоге њихове употребе. Проведена анализа одабраних дјела показује да се у Андрићевом књижевном тексту елементи, мањи или већи сегменти датих стилова појављују у различитим синтаксичким формама - у синтаксичкој форми управног говора, у форми реплика у дијалогу, као фрагментарни цитати у оквиру ауторског говора или као цитирани извори ортографски маркирани употребом наводника, у виду неуправног говора - и то не само у функцији говорне карактеризације лика, постизања одређеног аргументативног, естетског, иронијског или комичног ефекта већ и ради остварења критичке дистанце наспрам говорних представника датих стилова.

Укључењем специјалних функционалних стилова у језик књижевног дјела, писац нам, између осталог, разоткрива до које мјере овакви стилови, створени с циљем да се подупре и осигура процес комуникације (а чије су одлике тачност, прецизност, рационалност, објективност, склоност ка избјегавању препрека у комуникацији и стварању једнозначног, експлицитног исказа лишеног сваке недоумице), подвргнути процесу бирократизације могу дехуманизовати човјека, односе међу људима и постати моћно оруђе у рукама државе и владајуће идеологије, што се најбоље види у оним дијеловима текста гдје писац, у форми управног говора или у форми унутрашњег монолога, супротставља дате сти- 
Примјери употребе других функционалних стилова... 221

лове разговорном функционалном стилу као варијанти која је најједноставнија и човјеку најближа.

\section{Извори}

Ivo Andrić, Gospođica, u: Romani, Beograd: Laguna, 2014.

Иво Андрић, Изабрана проза (приповијетке), https://biblioteka. elektronskaknjiga.com/izabrana_proza.php. 25. 2. 2018.

НДТ: Ivo Andrić, Na Drini ćuprija, u: Romani, Beograd: Laguna, 2014. ОПЛ:Ivo Andrić, OmerpašaLatas, https://biblioteka.elektronskaknjiga. com/omer_pasa_latas.php. 25.2.2018.

ПКС: Прича о кмету Симану, у: Иво Андрић, Изабрана проза (приповијетке), https://biblioteka.elektronskaknjiga.com/ izabrana_proza.php. 25. 2. 2018.

TX: Ivo Andrić, Travnička hronika, u: Romani, Beograd: Laguna, 2014.

\section{Литература}

Белић 1937: А. Белић, Богаћење језика, Наш језик, год. V, св. 4, Београд: Лингвистичко друштво у Београду, 97-100.

Висковић 1989: N. Visković, Jezik prava, Zagreb: ITRO „Naprijed”. Зиновјев 2002: А. Зиновјев, Запад (феномен западюаштва), Београд, Lausanne: Наш дом, Age d' Homme.

Јовановић 2010: Ј. Јовановић, Лингвистика и стилистика новинског умећа, Београд: Јасен.

Катнић-Бакаршић 2001: M. Katnić Bakaršić, Stilistika, Sarajevo: NUK.

Ковачевић 2013: М. Ковачевић, Лингвистика као србистика, Источно Сарајево: Филозофски факултет у Источном Сарајеву.

Ковачевић 2015: М. Ковачевић, Српски језик између науке и политике, Бања Лука: Друштво наставника српског језика и књижевности Републике Српске.

Ковачевић 2016: М. Ковачевић, Књижевни језик и језик књижевности, у: М. Ковачевић (ред.), Српски језик, књижев- 
ност, уметност, књ. I, Језик, книжевност, уметност,

Крагујевац: Филолошко-уметнички факултет, 15-31.

Ковачевић 2017: М. Ковачевић, Специфични поступци пререгистрације у роману Кукавичја пилад Лабуда Драгића, Узданища, год. XIV, бр. 2, 25-41.

Силић 2006: J. Silić, Funkcionalni stilovi hrvatskoga jezika, Zagreb:

Disput.

Столац, Властелић 2014: Diana Stolac, Anastazija Vlastelić, Jezik reklama, Zagreb, Rijeka: Hrvatska sveučilišna naklada, Filozofski fakultet Sveučilišta u Rijeci.

Тошовић 2002: Б. Тошовић, Функционални стилови, Београд: Београдска књига.

Худечек, Михаљевић 2009: L. Hudeček, M. Mihaljević, Jezik medija - publicistički funkcionalni stil, Zagreb: Hrvatska sveučilišna naklada.

Veselina V. Đurkin

\section{EXEMPLARY OF THE USE OF NON-LITERARY FUNCTIONAL STYLES IN ANDRIĆ'S OPUS}

In this paper, starting from the collection of novels and short stories of Ivo Andrić, we analyse examples of using special functional styles - publicistic, official documents and scientific prose, predominantly the ways and reasons of their usage. The analysis of individual works shows that in Andrićs literary texts, the shorter or longer segments appear in different syntactic forms (in the form of direct speech, replicas in the dialogue, as fragmentary quotations of narrator's speech or quoted sources orthographically marked with quotation marks) with the goal not just to maintain speech quality of a character or produce a certain argumentative, aesthetic, ironical or comical effect, but also to achieve the critical distance from the speech representatives of these styles. Although created to strengthen and ensure the communication process, it can reverse its role and dehumanise a person or relationships between people or 
become a powerful tool in the hands of the state and the ruling ideology, which is best seen in those parts of the text where the writer, in the form of direct speech or internal monologue counterbalances the given styles to the colloquial style as a variant which is the most simple and closest to a person.

Key words: Ivo Andrić, belles-lettres style, special functional styles. 